\title{
Spatial variability of soil properties in the urban park before and after reconstruction
}

\author{
Romzaykina O.N. ${ }^{1}$, Vasenev V.I. ${ }^{1,}$, Khakimova R.R. ${ }^{1}$, Hajiaghayeva R. ${ }^{1}$, \\ Stoorvogel J.J. ${ }^{2}$, Dovletyarova E.A. ${ }^{1}$ \\ ${ }^{1}$ Department of Landscape Design and Sustainable Ecosystems, RUDN University, Moscow, Russia \\ ${ }^{2}$ Soil Geography and Landscape Group, Wageningen University, Wageningen, The Netherlands
}

\begin{abstract}
On-going urbanization stresses the necessity for structural and aesthetically organized urban landscapes to improve citizens' life quality. Recreational zones create a 'green frame' of a city and provide vital functions and services for city dwellers. This research focuses on the comparative analysis of spatial distribution of the key soil properties (acidity, organic carbon and nutrient contents) in the urban park named after Artyom Borovik (Moscow, Russia) before and after reconstruction. The maps of the urban soil's properties were created for both periods by interpolation of the field data, collected from the depths 0-30, 30-50 and 50-100 cm. The maps of the analyzed properties were developed using open Quantum GIS2.4 software by Inverse Distance Weighting (IDW). High spatial variability was observed for the soil properties with the highest variance reported for nutrient concentrations. High heterogeneity in $\mathrm{P}_{2} \mathrm{O}_{5}$ and $\mathrm{K}_{2} \mathrm{O}$ was obtained both in topsoil and subsoil, before and after reconstruction. We found that average concentrations of $\mathrm{P}_{2} \mathrm{O}_{5}$ and $\mathrm{K}_{2} \mathrm{O}$ were correspondingly above and below legal threshold taken for the Moscow city. As a result of the reconstruction the $\mathrm{pH}$ has changed from slightly acid and acidic to neutral and slightly alkaline. The topsoil soil organic carbon (SOC) content has increased in result of reconstruction but still was below threshold, recommended by municipal regulations. The findings of the research can be used to project possible changes in soil cover resulted from expansion and reorganization of green areas, which is essential to support decisions in urban planning and soil management in sustainable cities.
\end{abstract}

Key words: Urbanization, urban soils, spatial variability, temporal dynamics, digital soil mapping

\section{Introduction}

Urbanization is among the main current land-use change trends worldwide (Pickett et al., 2011). More than half of the global population currently lives in cities (UN, 2014) and up to two thirds of the world population is projected to live in cities by 2050 (FAO, 2013). Urban ecosystems provide a combination of environmental, social and economic functions, affecting life quality of city dwellers (Denisov et al., 2008). Urban soils and vegetation are the main components of urban ecosystems, responsible for the key ecosystem services (Pickett et al., 2008; Raciti et al., 2011). In result of the anthropogenic influence, urban soils and vegetation are very different from natural ones and vary from pseudo-natural to artificial soils and introduced plant species (Levin et al., 2017). Land-use and functional zoning are key factors, driving spatial variability of vegetation and soils inside city boundaries, with more natural plant-soil associations in recreational and suburb areas and more disturbed plant communities and artificial soils in industrial areas and road sides (Ghosh et al., 2016; Huot et al., 2017). Nevertheless, the heterogeneity of soils and vegetation within functional zones is also high and depends on both land-use history and current management practices.

Recreational zones and first of all urban parks create a 'green frame' of a city and provide vital functions and services for city dwellers. For example, trees and shrubs absorb contaminants (hydrocarbons, sulfates, heavy metals and particle matters), emitted by industries and traffic (Dovletyarova et al., 2017). Vegetation and soils of urban parks contribute to carbon sequestration and nitrogen deposition (Svirejeva-Hopkins et al., 2004; Raciti et al., 2011). Moreover, urban greenery regulates microclimate by mitigating urban heat island effect (Kislov and Konstantinov, 2011) and supports biodiversity in urban areas (McKinney, 2006). Soils of urban parks play an essential role for the growth and development of plants, however other soil functions, such as ground water protection, buffering contaminants and carbon sequestration and storage, are also very important (Kurbatova et al., 2004; Morel et al., 2014).

Urban soils are subjected to high anthropogenic influence, therefore, they are extraordinary in terms of properties and parameters of ecological functioning (Vasenev et al., 2012). In general, urban soils are

\footnotetext{
*Email: olrom92@mail.ru
} 

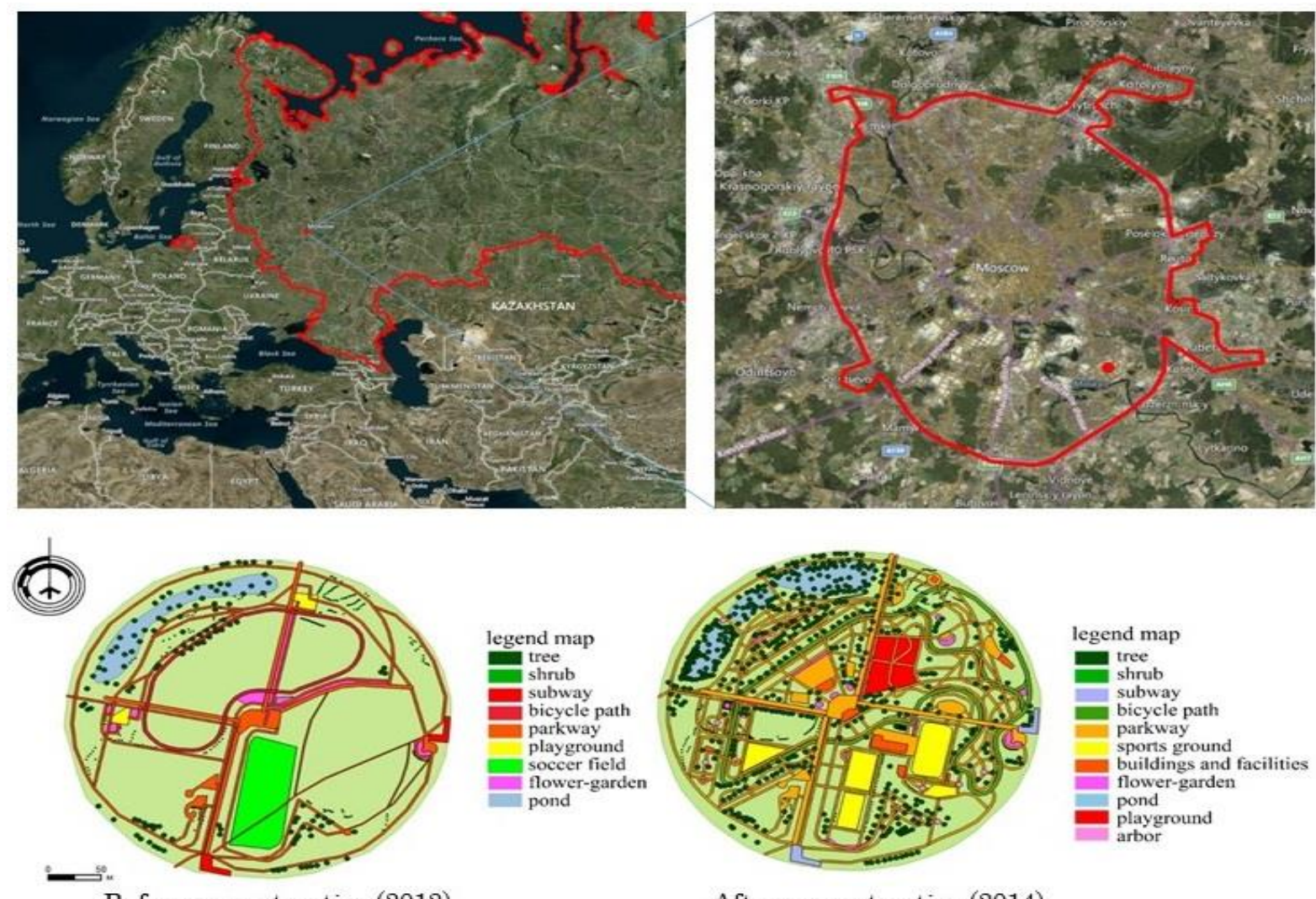

legend map

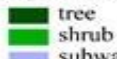

shrub
subway
bicycle path

parkway

sports ground

buildings and facilities

flower-garden

pond

playground

Before reconstruction (2012)

After reconstruction (2014)

Figure 1: Research area
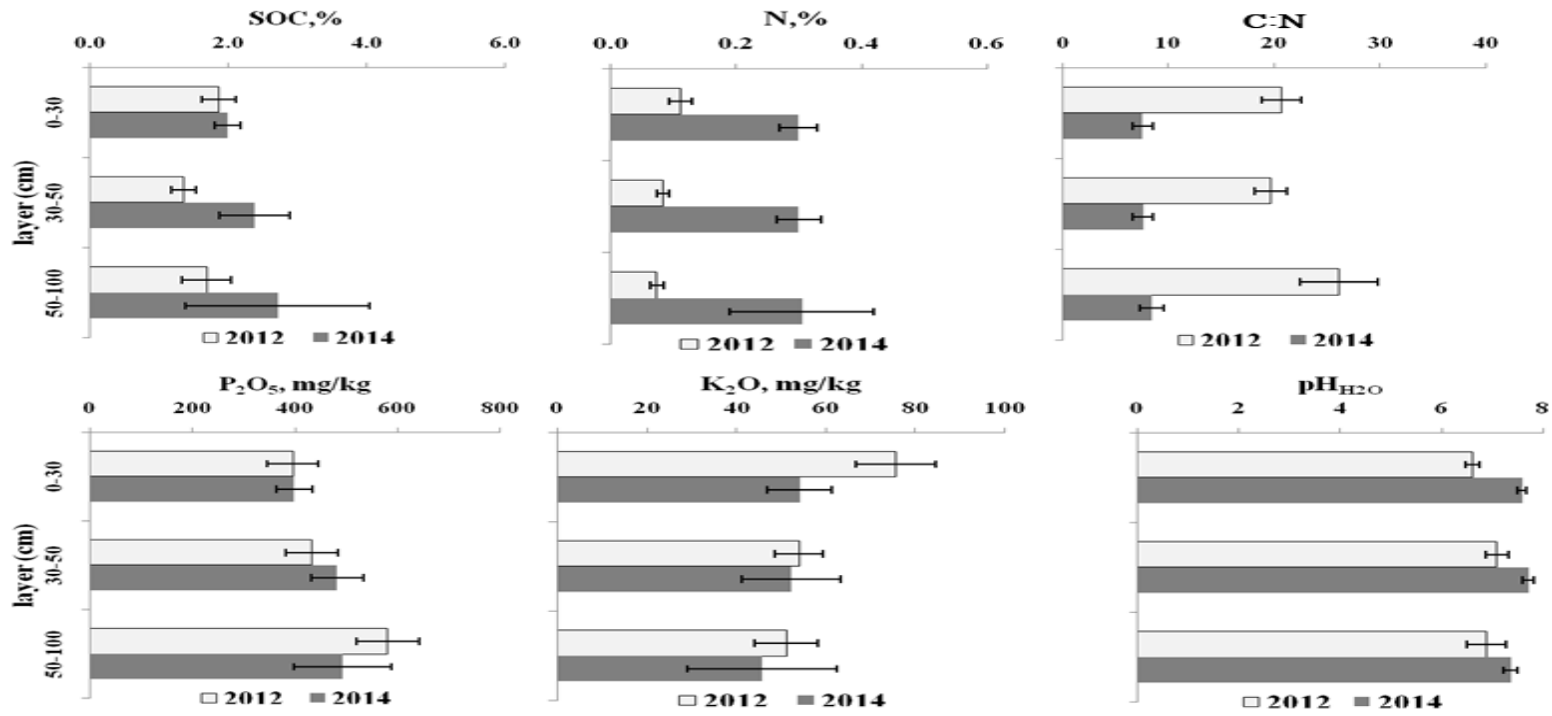

Figure 2: Soil properties in 0-30, 30-50 and 50-100 cm layers before and after reconstruction

characterized by specific morphological properties (variety of soil layers with abrupt borders and abundance of anthropogenic inclusions), over-compaction, slightly alkaline $\mathrm{pH}$ and increased concentrations of contaminants 
(heavy metals, salts, building and household wastes) (Gerasimova et al., 2003; Rossiter, 2007; Yang et al., 2016). Besides, urban soils are very variable in space and time (Vasenev et al., 2014), which constrains considering soil information in land-use and management planning. Land cover and zoning (i.e. lawns, flower-beds, shrubs and trees) determine spatial variability of soil properties in urban parks whereas temporal dynamics results from such human-driven processes as managing and reconstructing green spaces (Bae and Ryu, 2015). Dozens of parks are annually created or reconstructed in each large city over the globe; however, the possible consequences for soil properties are rarely investigated. Reconstruction often coincides with substantial land-cover changes. Various reconstruction processes (e.g., excavations, leveling, constructing pathways, planting trees and adding composts) can completely alter spatial variability of soil properties in an urban park.

Changes in urban soils' properties and their spatial patterns in result of reconstruction have rarely been studied thoroughly. The up-date soil information is necessary as a basis for decision-making in landscaping, introducing and maintaining ornamental plants and green infrastructures. Novel methodologies of spatial analysis, including interpolation and extrapolation techniques, available in geographic information system (GIS)-software, allow mapping soil properties for the different time periods and based on the limited amount of field data (McBratney et al., 2000; 2003; Rizwan et al., 2016). Comparison of initial and final land cover and zoning in the park (i.e. lawns, flowerbeds, shrubs and trees) and soil properties before and after reconstruction allows predicting and mapping the effect of land-cover change and reconstruction processes on soils in urban parks.

This research focuses on the comparative analysis of the spatial distribution of the key soil properties (acidity, organic carbon and nutrient contents) in the urban park named after Artyom Borovik (Moscow, Russia) before and after reconstruction.

\section{Materials and Methods}

\section{Research area}

The research was conducted in the urban park named after Artyom Borovik, located in South-Eastern Administrative District of Moscow. Moscow is the capital of Russia and one of the most densely urbanized areas in Europe (Argenbright, 2011). Moscow locates in the center of the East European Plain on the Moscow river in the interfluve of Oka and Volga. The average altitude is $180 \mathrm{~m}$. The climate is temperate continental with the mean annual temperature of $5.8^{\circ} \mathrm{C}$ and average annual precipitation of
$600 \mathrm{~mm}$. The natural vegetation of southern taiga partially remains in urban forest and natural protected areas, however the introduced species (i.e. linden, poplar, maple, chestnut, birch, etc.) dominate the recent vegetation of Moscow. The natural soil cover of the territory is dominated by zonal Eutric Podzoluvisols and intrazonal Dystric and Eutric Luvisols located in the flood-plains of Moscow (Stroganova et al., 1997; Shishov and Voitovich, 2002). However, urbanization has resulted in substantial soil transformations. Currently initial natural soils are substituted by semi-natural or completely artificial urban soils of different sub-types, e.g. 'urbanozems', 'replantozems', 'ekranozems' etc. (Gerasimova et al., 2003; Vasenev et al, 2012; Prokofieva et al., 2011, 2014).

Historically the research area was used for residence and municipal needs. The earliest information on the territory dates back to the $17^{\text {th }}$ century when it belonged to the Marino village. In the beginning of the $20^{\text {th }}$ century the area was partly occupied by the Lublin aeration fields, where the sewage water was collected and purified. In 1960-s the area was included into the growing Moscow city the fields were abandoned and the surrounding area was partly built-up. Finally, an urban park was established in 1996 to improve the environmental conditions of the district and to create new capacities for recreation (Vasenev et al., 2012). The park locates inside a large circle of roads at the crossroads of Bratislavskaya street and Pererva street $\left(55^{\circ} 39^{\prime} 42^{\prime \prime} \mathrm{N}, 37^{\circ} 45^{\prime} 22^{\prime \prime} \mathrm{E}\right)$ and occupies an area of 10.4 hectares. The zoning of the park has changed substantially after the reconstruction occurred in 2013. Before the reconstruction a pond, surrounded by trees and shrubs was located in the north-western part. Several artificial hills vegetated with birches occupied the south-western and south-eastern part of the park. An unequipped football field was located in the south-western part. In results of the reconstruction in 2013 the new zoning and land cover structure of the park was created. The new structure has divided the territory by the main roads into four thematic parts, the pond and the artificial hills. The park was revegetated, new walking paths were created and the old ones were replaced. Other renovations included creating bikeways, sports and playgrounds, attractions, rental agency, the summer cinema, ice rink with artificial ice, arbors, and lighting throughout (Figure 1). After the revegetation the greenery in the park was dominated by maple, willow, birch and linden, whereas soils were dominated by 'recreazems' and urban constructed soils.

\section{Soil survey}

Soil survey in the park was held before and after reconstruction (in 2012 and 2014 respectively). Before the reconstruction soils were sampled using the uniform design 
(the net with $100 \mathrm{~m}$ side and key plots with $50 \mathrm{~m}$ and $10 \mathrm{~m}$ size). After the reconstruction, additional samples were collected at locations, where the land cover and functional zone had changed in result of the reconstruction. Data reconnaissance was conducted prior to sampling. The landcover change pathways resulted from reconstruction in 2013 were analyzed and representative inspection points were selected. In total 439 samples from 110 points were collected in the park and surrounding residential areas in 2012 (Vasenev et al., 2012). After the reconstruction, 20 additional points were observed at locations, where the changes in land cover and zoning could have substantial influence on soil properties. Samples were collected by auguring to a depth of $0-30 \mathrm{~cm}$, since this was depth mainly affected by reconstruction. Samples at five random points were collected to the $100 \mathrm{~cm}$ depth to describe profile distribution. The following chemical properties were analyzed in the collected samples: $\mathrm{pH}_{\mathrm{H} 2 \mathrm{O}}$ (potentiometric methods); SOC content (dichromate oxidation method), $\mathrm{P}_{2} \mathrm{O}_{5}$ (Kirsanov method), $\mathrm{K}_{2} \mathrm{O}$ (flame photometry) and $\mathrm{N}_{\text {tot }}$ (combustion).

\section{Data analysis and soil mapping}

The data was processed by descriptive statical tools and expressed as mean \pm standard error. Significance of the difference in soil properties was checked by an independent T-test (since the sample size differed between the years). Relationships between different soil properties were analyzed through Pearson's correlation coefficient. Soil maps were created in QGIS software (http://www.qgis.org) by IDW at a Distance coefficient $P$ value of 2, which is widely used for mapping soil properties affected by landuse change (Hengl et al., 2007; Ahmed et al., 2017).

\section{Results}

\section{Soil properties in the urban park before and after reconstruction}

The analyses showed an average SOC content of $1.85 \pm 0.26 \%$ in topsoil $(0-30 \mathrm{~cm})$ of the urban park before the reconstruction. Considering total $\mathrm{N}$ content ranged from 0.4 to 0.27 an average $\mathrm{C}: \mathrm{N}$ ratio was just $21 \pm 2$ which is considerably lower than in zonal Eutric Podzoluvisols and indicates a poor quality of organic matter (Batjes, 1996; Ali and Nabi, 2016). Soil $\mathrm{pH}_{\mathrm{H} 2 \mathrm{O}}$ in the park was close to neutral in comparison to the slightly acid reaction reported for the natural Eutric Podzoluvisols in the Moscow region (Shishov and Voitovich, 2002). High $\mathrm{P}_{2} \mathrm{O}_{5}$ contents of almost $400 \mathrm{mg} / \mathrm{kg}$ were obtained at the research site, however the coefficient of variance $66 \%$ indicates high spatial variability in this property. In contrast, $\mathrm{K}_{2} \mathrm{O}$ content was limited (below $100 \mathrm{mg} / \mathrm{kg}$ recommended for urban soils by GO-514 regulations) and less heterogeneous.
Different profile distribution was shown for various soil properties. For example, average $\mathrm{N}$ and $\mathrm{K}_{2} \mathrm{O}$ contents decreased $30 \%$ in 50-100 cm compared to the topsoil. An opposite pattern was found for $\mathrm{P}_{2} \mathrm{O}_{5}$ contents, which increased almost 50\%. Differences in SOC contents and $\mathrm{pH}_{\mathrm{H} 2 \mathrm{O}}$ between soil layers were not significant, however $\mathrm{C}: \mathrm{N}$ ratio in the deeper layers was higher compared to topsoil (Figure 2).

The reconstruction of the park has affected all the investigated soil properties, however, its effect differed between the layers and individual properties. An independent T-test confirmed that top layers (0-30 and 30$50 \mathrm{~cm}$ ) were more exposed to changes by reconstruction, since more than half of the investigated soil properties changed significantly in these layers (Table 1). In the top 0$30 \mathrm{~cm}$ layer, the reconstruction resulted in remarkable changes in $\mathrm{pH}_{\mathrm{H} 2 \mathrm{O}}$, SOC and $\mathrm{N}$ contents and $\mathrm{C}: \mathrm{N}$ ratio. After the reconstruction, soil reaction increased more than one $\mathrm{pH}_{\mathrm{H} 2 \mathrm{O}}$ unit and shifted from slightly acid to slightly alkaline. The average SOC and N contents in $0-30 \mathrm{~cm}$ were correspondingly $10 \%$ and almost two times higher than before the reconstruction, which resulted in decreasing $\mathrm{C}: \mathrm{N}$ ratio almost three times. In the layer $30-50 \mathrm{~cm}$, the reconstruction had a significant effect on even higher amount of properties compared to $0-30 \mathrm{~cm}$ layer (4 over 3 properties), however, the differences in the properties' values before and after reconstruction were less evident. In contrast to the $0-30 \mathrm{~cm}$ layer, $\mathrm{pH}_{\mathrm{H} 2 \mathrm{O}}$ and $\mathrm{SOC}$ and $\mathrm{N}$ content after the reconstruction was lower and $\mathrm{C}: \mathrm{N}$ ration was higher than before the reconstruction. For both in $0-30 \mathrm{~cm}$ and $30-50 \mathrm{~cm}$ layers the obtained changes in $\mathrm{P}_{2} \mathrm{O}_{5}$ contents before and after reconstruction were negligible. An average content of $\mathrm{K}_{2} \mathrm{O}$ in $0-30 \mathrm{~cm}$ decreased one third after reconstruction and was just half from the recommended values (GO-514). Changes of soil properties at $50-100 \mathrm{~cm}$ were not statistically significant (t-test, $p>0.05$ ), except for $\mathrm{N}$ content which increased four times. In general, the patterns described for 0-50 were similar to those in topsoil an increase in $\mathrm{pH}_{\mathrm{H} 2 \mathrm{O}}, \mathrm{SOC}$ and $\mathrm{N}$ and decrease in $\mathrm{C}: \mathrm{N}$ ratio (Figure. 2).

\section{Spatial variability of land-cover and soil properties in the urban park}

Although the difference in average values of soil properties before and after reconstruction was clearly shown, it doesn't reflect spatial distribution of soil parameters in both periods. High spatial variability was shown for the investigated soils properties both before and after reconstruction. SOC and nutrients' contents were the most variable soil properties in the urban park before reconstruction with the variance coefficients $(\mathrm{CV}) 55-60 \%$ for the topsoil. At the deeper layers $\mathrm{CV}$ of $\mathrm{N}, \mathrm{P}_{2} \mathrm{O}_{5}$ and $\mathrm{K}_{2} \mathrm{O}$ 
Table 1: Comparison of soil properties in 2012 and 2014 by T-test

\begin{tabular}{|c|c|c|c|c|c|}
\hline Soil property & Mean 2012 & Mean 2014 & T-value & $\begin{array}{c}\text { Degrees of } \\
\text { freedom }\end{array}$ & p-level \\
\hline \multicolumn{6}{|c|}{$0-30 \mathrm{~cm}$} \\
\hline $\mathrm{pH}_{\mathrm{H} 2 \mathrm{O}}$ & $6.61 \pm 0.14$ & $7.58 \pm 0.09$ & -5.61240 & 37 & $0.000002 *$ \\
\hline Corg, $\%$ & $1.85 \pm 0.26$ & $1.99 \pm 0.21$ & -0.41335 & 38 & 0.681675 \\
\hline Ntot, $\%$ & $0.11 \pm 0.002$ & $0.30 \pm 0.031$ & -5.50357 & 23 & $0.000013^{*}$ \\
\hline $\mathrm{P}_{2} \mathrm{O}_{5}, \mathrm{mg} / \mathrm{kg}$ & $395.87 \pm 50.52$ & $399.17 \pm 42.37$ & -0.05051 & 39 & 0.959972 \\
\hline $\mathrm{K}_{2} \mathrm{O}, \mathrm{mg} / \mathrm{kg}$ & $75.64 \pm 8.77$ & $54.19 \pm 4.11$ & 1.82032 & 39 & 0.076391 \\
\hline $\mathrm{C}: \mathrm{N}$ & $20.65 \pm 1.86$ & $7.59 \pm 1.00$ & 4.62881 & 23 & $0.000117 *$ \\
\hline \multicolumn{6}{|c|}{$30-50 \mathrm{~cm}$} \\
\hline $\mathrm{pH}_{\mathrm{H} 2 \mathrm{O}}$ & $7.71 \pm 0.23$ & $7.09 \pm 0.11$ & 2.12951 & 28 & $0.042141^{*}$ \\
\hline Corg, $\%$ & $2.38 \pm 0.39$ & $1.36 \pm 0.49$ & 2.37753 & 24 & $0.025743^{*}$ \\
\hline Ntot, $\%$ & $0.30 \pm 0.009$ & $0.08 \pm 0.030$ & 8.73689 & 20 & $0.000000^{*}$ \\
\hline $\mathrm{P}_{2} \mathrm{O}_{5}, \mathrm{mg} / \mathrm{kg}$ & $482.17 \pm 50.6$ & $433.16 \pm 49.49$ & 0.63311 & 31 & 0.531303 \\
\hline $\mathrm{K}_{2} \mathrm{O}, \mathrm{mg} / \mathrm{kg}$ & $52.34 \pm 5.38$ & $54.06 \pm 12.74$ & -0.15785 & 31 & 0.875603 \\
\hline $\mathrm{C}: \mathrm{N}$ & $7.60 \pm 0.93$ & $19.67 \pm 1.52$ & -4.17304 & 20 & $0.000469 *$ \\
\hline \multicolumn{6}{|c|}{$50-100 \mathrm{~cm}$} \\
\hline $\mathrm{pH}_{\mathrm{H} 2 \mathrm{O}}$ & $6.88 \pm 0.39$ & $7.36 \pm 0.13$ & 0.82221 & 20 & 0.420653 \\
\hline Corg, $\%$ & $1.68 \pm 0.38$ & $2.71 \pm 0.42$ & 0.92398 & 17 & 0.368429 \\
\hline Ntot, \% & $0.07 \pm 0.011$ & $0.31 \pm 0.098$ & 5.23976 & 15 & $0.000100^{*}$ \\
\hline $\mathrm{P}_{2} \mathrm{O}_{5}, \mathrm{mg} / \mathrm{kg}$ & $580.89 \pm 61.67$ & $493.00 \pm 117.21$ & -0.77371 & 22 & 0.447338 \\
\hline $\mathrm{K}_{2} \mathrm{O}, \mathrm{mg} / \mathrm{kg}$ & $51.26 \pm 7.02$ & $45.75 \pm 23.47$ & -0.36376 & 22 & 0.719506 \\
\hline $\mathrm{C}: \mathrm{N}$ & $24.12 \pm 5.70$ & $8.44 \pm 1.18$ & -1.40001 & 7 & 0.204238 \\
\hline
\end{tabular}

* - statistically significant difference $(\mathrm{p}<0.05)$

Table 2: Topsoil $(0-30 \mathrm{~cm})$ properties under different land-cover before and after reconstruction

\begin{tabular}{|c|c|c|c|c|c|}
\hline Land-cover & $\mathbf{p H}_{\mathbf{H 2 O}}$ & $\mathbf{C o r g}, \mathbf{\%}$ & $\mathbf{N t o t}, \mathbf{~ m g} / \mathbf{k g}$ & $\mathbf{P}_{\mathbf{2}} \mathbf{O}_{\mathbf{5}}, \mathbf{~ m g} / \mathbf{k g}$ & $\mathbf{K}_{\mathbf{2}} \mathbf{O} \mathbf{~} \mathbf{~ g} / \mathbf{k g}$ \\
\hline Lawn $\frac{2012}{2014}$ & $\frac{6.6 \pm 0.72}{7.6 \pm 0.51}$ & $\frac{1.8 \pm 0.98}{2.3 \pm 0.67}$ & $\frac{0.1 \pm 0.07}{0.3 \pm 0.09}$ & $\frac{358.1 \pm 233.09}{356.9 \pm 175.95}$ & $\frac{77.2 \pm 38.61}{63.4 \pm 34.20}$ \\
\hline Trees $\frac{2012}{2014}$ & $\frac{6.03}{7.6 \pm 0.21}$ & $\frac{1.01}{1.6 \pm 0.71}$ & $\frac{0.06}{0.3 \pm 0.09}$ & $\frac{303.10}{427.4 \pm 126.31}$ & $\frac{34.71}{64.0 \pm 36.94}$ \\
\hline Shrubs $\frac{2012}{2014}$ & $\frac{6.8 \pm 0.43}{7.7 \pm 0.43}$ & $\frac{2.2 \pm 1.76}{1.4 \pm 0.37}$ & $\frac{0.2 \pm 0.10}{0.18}$ & $\frac{545.1 \pm 288.73}{431.1 \pm 240.70}$ & $\frac{84.5 \pm 58.67}{42.4 \pm 24.32}$ \\
\hline Wetland $\frac{2012}{2014}$ & $\frac{6.43}{7.2 \pm 0.15}$ & $\frac{0.97}{2.2 \pm 1.27}$ & $\frac{0.04}{n . d .}$ & $\frac{347.05}{428.6 \pm 95.11}$ & $\frac{47.77}{29.6 \pm 9.10}$ \\
\hline Flowerbed $\frac{2012}{2014}$ & $\frac{n . d .}{7.7 \pm 0.54}$ & $\frac{n . d .}{2.5 \pm 1.40}$ & $\frac{n . d .}{0.31}$ & $\frac{n . d .}{413.3 \pm 71.33}$ & $\frac{n . d .}{44.6 \pm 22.39}$ \\
\hline
\end{tabular}

contents decreased to $45-50 \%$, however $\mathrm{CV}$ of SOC contents increased to more than $85 \%$. Less variability was reported for $\mathrm{pH}_{\mathrm{H} 2 \mathrm{O}}-\mathrm{CV}$ values were 10,13 and $22 \%$ for 0 $30, \quad 30-50$ and 50-100 cm correspondingly. The reconstruction of the urban park resulted in slight decrease of variance in soils properties. The highest 60-80\% CV values were obtained for $\mathrm{P}_{2} \mathrm{O}_{5}$ and $\mathrm{K}_{2} \mathrm{O}$ contents, whereas
CVs for SOC and $\mathrm{N}$ contents were $35-50 \%$ and for $\mathrm{pH}_{\mathrm{H} 2 \mathrm{O}}-$ just $5 \%$.

Land cover and functional zoning were the main factors driving spatial variability of soil properties in 2012 . In result of the reconstruction the total areas covered by lawns reduced, whereas, areas covered by trees and shrubs increased, and new flower beds were made (Figure 3). 
Changes in land-cover structure by reconstruction resulted in corresponding changes in spatial patterns of soil properties. . The analysis of soil samples collected in 2012 showed that topsoils under shrubs and lawns contained two times higher amounts of SOC and $\mathrm{N}$ and 30-50\% higher amounts of $\mathrm{P}_{2} \mathrm{O}_{5}$ and $\mathrm{K}_{2} \mathrm{O}$ than it was obtained for another functional zones. The lowest $\mathrm{C}: \mathrm{N}$ ratio of 13 was also obtained for shrubs, whereas the highest value 24 was shown for wetlands. Soils under lawns and trees didn't differ significantly with $\mathrm{C}: \mathrm{N}$ ratios 18 and 17 correspondingly. The highest and the most close to neutral $\mathrm{pH}_{\mathrm{H} 2 \mathrm{O}}$ was shown for soils under shrubs and the lowest for areas covered by trees, however the differences in this property were not statistically significant. Similar patterns were reported for subsoils with the most favorable soil agrochemical conditions under shrubs and relatively poor soils in wetland areas. After the reconstruction, the highest topsoil SOC and N contents were shown for lawns and new created flower beds. Soils under shrubs contained $60 \%$ less SOC and N compared to lawns and flower beds. Soils under trees contained more $\mathrm{P}_{2} \mathrm{O}_{5}$ and soils covered by shrubs more $\mathrm{K}_{2} \mathrm{O}$ compared to other functional zones. However, for all functional zones except lawns, $\mathrm{P}_{2} \mathrm{O}_{5}$ concentrations were above and $\mathrm{K}_{2} \mathrm{O}$ concentrations were below the recommended values (GR-514). Functional zones didn't differ in $\mathrm{pH}_{\mathrm{H} 2 \mathrm{O}}$ significantly with slightly lower values in wetlands and slightly higher values in lawns (Table 2). Profile distributions of soil properties were similar between most of the functional zones and were well approximated by the average values described in Table 1. An exception was a different pattern in SOC and $\mathrm{N}$ profile distribution in soils under trees and lawns (Table 2).

\section{Comparison of the soil maps}

The maps of the urban soil's properties for both periods (2012 and 2014) were created by interpolation of the field data. Mapping exercise was done only for the top 0-30 layer, considering the highest sampling density for the topsoil, which could support the highest accuracy comparing to deeper horizons. The maps were used to assess the spatial patterns in the investigated soil properties before and after reconstruction. Comparison of the maps of 2012 and 2014 allowed assessing the influence of changes in land-cover structure on soil properties. The maps of soil properties before the reconstruction are more 'patchy', whereas the maps after reconstruction are more homogeneous. Several 'hotspots' are clearly visible on the maps of 2012 at the North-West and East and South-East parts. The area in the North-West with low SOC contents and slightly acid $\mathrm{pH}_{\mathrm{H} 2 \mathrm{O}}$ refers to the wetland. The area in the East with increased SOC contents $\mathrm{P}_{2} \mathrm{O}_{5}$ and corresponds with the shrub plantations, whereas the area in South-East with low SOC contents and neutral $\mathrm{pH}_{\mathrm{H} 2 \mathrm{O}}$ is a walking zone at the bottom of the artificial hill. The maps of 2014 indicate higher homogeneity of soil properties after reconstruction. The maps of $\mathrm{P}_{2} \mathrm{O}_{5}, \quad \mathrm{~K}_{2} \mathrm{O}$ are quite homogeneous with smooth boundaries between functional zones. The maps of SOC contents and $\mathrm{pH}_{\mathrm{H} 2 \mathrm{O}}$ are more patchy with higher $\mathrm{SOC}$ contents and $\mathrm{pH}_{\mathrm{H} 2 \mathrm{O}}$ values in location of shrubs and trees plantation and new flower beds (Figure 4)

\section{Discussion}

\section{Spatial variability of soil properties in urban parks}

Soils of urban recreational zones are usually less exposed to anthropogenic disturbance and therefore are expected to have higher quality compared to soils of other functional zones. Some papers also report on lower heterogeneity of urban parks' soils in comparison to residential, industrial or public areas (Vasenev et al., 2014; Smorkalov and Vorobeichik, 2015; Horváth et al., 2017). Lower level of disturbance and a relative homogeneity promotes urban parks as a typical reference sites for soil monitoring (Ivashchenko et al., 2014; Khan et al., 2017). In our research we analyzed spatial variability and soil properties of the urban park in Moscow megapolis. The investigated soil properties were quite similar to those described for the recreational zones in Moscow and other cities with similar boreal climate (Pouyat et al., 2015; Rozanova et al., 2016), however differed from the results obtained for urban parks in other climatic conditions (Sarzhanov et al., 2015; Ghosh et al., 2016). Soil conditions of urban parks are usually more similar to natural ones than those of more disturbed urban soils, therefore the bioclimatic factor dominates in soil formation and features. In result, soils of recreational areas located in different climatic zones differ much more than soils of industrial or residential zones. The SOC and $\mathrm{N}$ contents in the investigated soils of the urban park were higher than in forested or arable lands in the Moscow regions (Shishov and Voitovich, 2002; Nilsson et al., 2002; Kurganova et al., 2014), but were lower than in some residential areas and even industrial areas (Prokofieva et al., 2013; Vasenev et $a l ., 2013)$. This is likely explained by more intensive soil management and adding of organic substrates e.g. composts and turf-sand mixtures (Lorenz and Lal, 2009; Shchepeleva et al., 2016). High microbiological activity and soil respiration usually reported for recreational zones (Livesley et al., 2010; Ivashchenko et al., 2014) facilitate faster decomposition of SOC. The $\mathrm{pH}_{\mathrm{H} 2 \mathrm{O}}$ was slightly higher than in natural reference areas but lower than in average 7.0-7.5 reported for Moscow city (Kulbachevksy, 2015). Neutral and slightly alkaline reaction in urban soils is conventionally explained by lime input from cement dust 

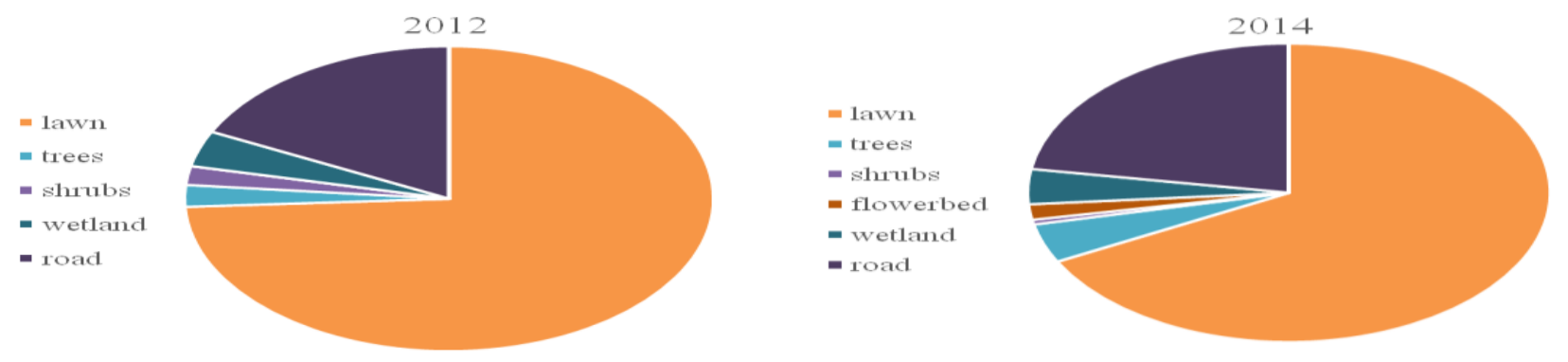

Figure 3: Land-cover structure in the urban park before and after reconstruction

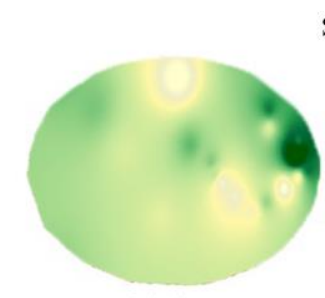

2012

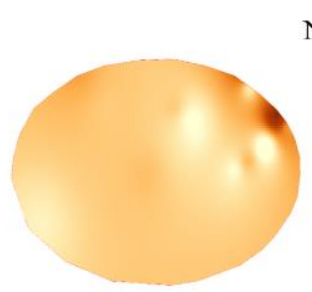

2012

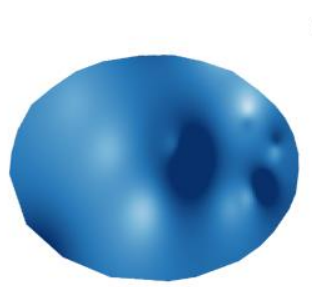

2012
SOC, $\%$

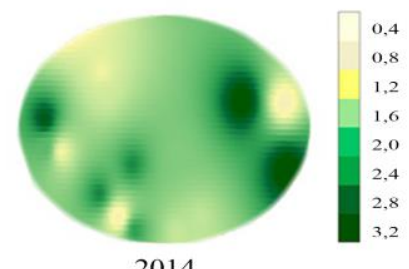

N, \%

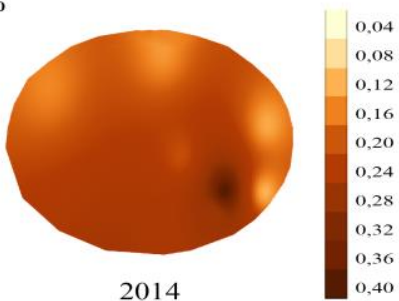

$\mathrm{C}: \mathrm{N}$

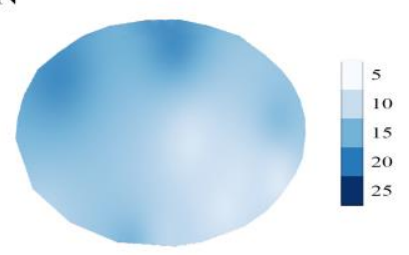

2014

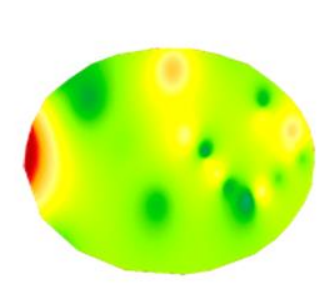

2012

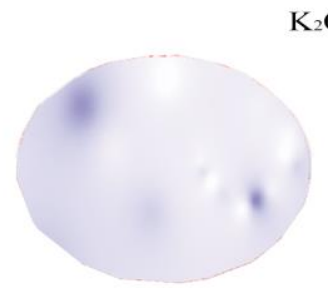

2012
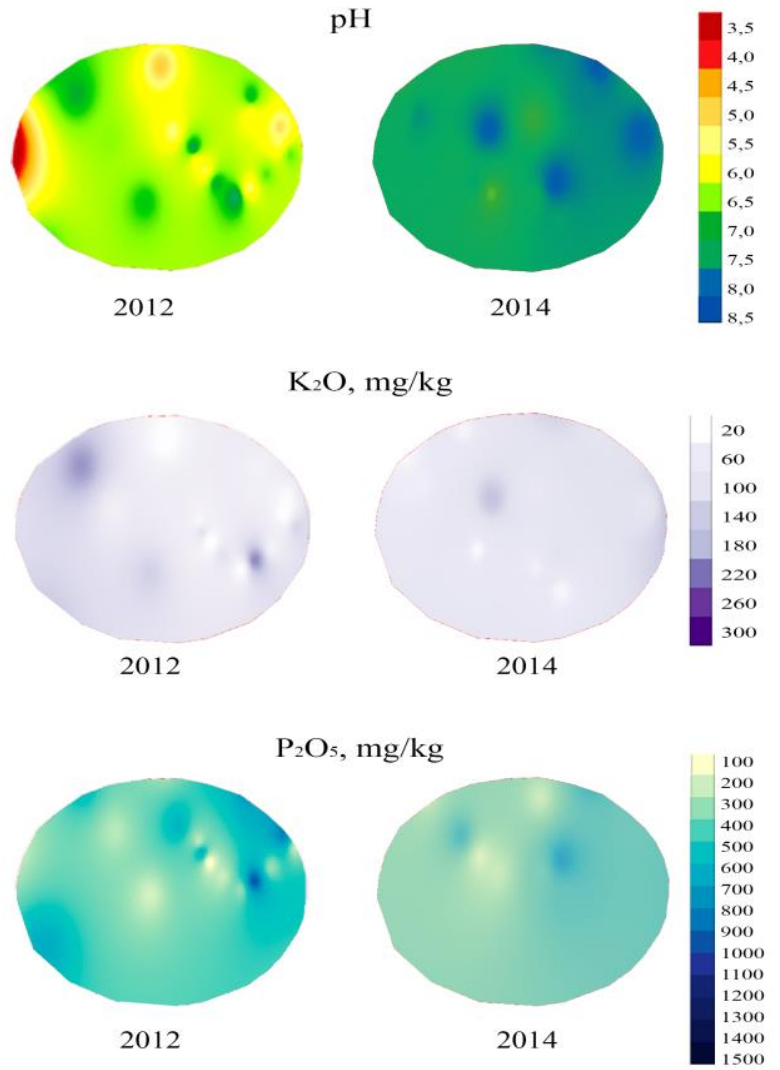

$\mathrm{K}_{2} \mathrm{O}, \mathrm{mg} / \mathrm{kg}$

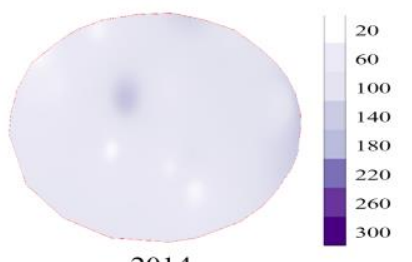

2014

We observed an increased $\mathrm{P}_{2} \mathrm{O}_{5}$ contents in the park. Likely it can be explained by the additional inputs of phosphorous with faeces of domestic animals that walk in the park.

The created maps of soil properties show a high spatial variability, which is also confirmed by the estimated CVs of $50-60 \%$ for most of the properties. These values are

Figure 4: Maps of soil properties $(0-30 \mathrm{~cm}$ layer) before and after reconstruction

and concrete particles from building sites and cement factories, present in almost all cities (Washbourne et al., 2012; Lorenz and Lal, 2015). Existing regulations of soils quality for landscaping also proposes $\mathrm{pH}_{\mathrm{H} 2 \mathrm{O}}=6.5$ as a lower threshold for lawns, trees and shrubs (GR-514). The same regulations control nutrients' contents in urban soils. 
comparable to those reported for urban soils (Vasenev et al., 2014; Ivashchenko et al., 2014), but higher than it was expected for a recreational zone. A diverse land cover structure may be the main reason for high variability of soil properties. Soils in areas exposed to more intensive management (lawns, shrubs and flowerbeds) contained more SOC and nutrients than others. The soil $\mathrm{pH}_{\mathrm{H} 2 \mathrm{O}}$ in 'natural' areas (wetland and tree stands) were lower than in the more 'artificial' lawns and flower beds. Land cover structure was the main factor influencing spatial variability of soil properties in the park and therefore changes in land cover after reconstruction affected the distribution of soil properties.

\section{The effect of reconstruction on soil properties}

Soil disturbance during park reconstruction is one of the primary reasons for temporal dynamics in soil properties. Different management practices and soil processes coincided with different functional zones and land cover types result in new patterns in spatial distribution of soil properties. For example, the reconstruction of the Seoul Forest Park resulted in remarkable increase in SOC contents, and also increased spatial variability of SOC (Bae and Ryu, 2015). An increase of bulk density and $\mathrm{pH}_{\mathrm{H} 2 \mathrm{O}}$ was reported for the reconstructed plots in the urban forest park in Moscow (Dovletyarova et al., 2017). In the investigated areas we found remarkable changes in soil properties of before and after reconstruction with different patterns obtained for 030 and $30-50 \mathrm{~cm}$ layers. Increased $\mathrm{SOC}$ and $\mathrm{N}$ contents, decreased $\mathrm{C}: \mathrm{N}$ ratio and increased $\mathrm{pH}_{\mathrm{H} 2 \mathrm{O}}$ were the most evident changes in $0-30 \mathrm{~cm}$ soil layer after reconstruction. Higher SOC contents and a substantial decrease in C:N ratio from $15-20$ in 2012 to 5-10 in 2014 indicates a high quality of organic substances implemented for landscaping during the reconstruction. Neutral and slightly alkaline $\mathrm{pH}_{\mathrm{H} 2 \mathrm{O}}$ was likely caused by fertilizers and soil amendments used for establishing lawns and flower beds. Engineering and constructing works using cement and other limecontaining material e.g. for making walking paths and building basements for new pavilions, likely contributed to higher average $\mathrm{pH}_{\mathrm{H} 2 \mathrm{O}}$ and to homogenization of soil $\mathrm{pH}_{\mathrm{H} 2 \mathrm{O}}$ within park boundaries. In contrast to topsoil, decrease in SOC and $\mathrm{N}$ contents in $30-50 \mathrm{~cm}$ after reconstruction may be caused by leaching and depletion of nutrients. As a rule, composts and fertilizers are added to soil surfaces, whereas the main root zone and correspondingly maximal nutrient consumption for shrubs and trees is at the depth of $50 \mathrm{~cm}$ and below.

Transformations from lawns to flower-beds and from wetlands to trees and shrubs were the most beneficial in terms of the positive changes in soil properties, including increased $\mathrm{pH}_{\mathrm{H} 2 \mathrm{O}}, \mathrm{SOC}$ and $\mathrm{N}$ contents. However, remarkable changes of some soil properties were found even for the areas, where land cover remained unchanged. For instance, $\mathrm{pH}_{\mathrm{H} 2 \mathrm{O}}$ in soil under lawns in 2014 was $0.5-1.0$ unit higher than in 2012. Likely, it was caused by the deposition of cement dust from constructing works in the park. Judging by maps and CV estimates, the spatial variability of soil properties has decreased after the reconstruction. It can be explained by similar treatments and procedures implemented during the reconstruction, including excavating and translocation of topsoil masses, adding composts, fertilizers and amendments. Likely, in the course of time different management practices will result in more specific soil properties under different land-covers. Exclusion of the roads and pavements from the analysis could also artificially reduce spatial variability and add uncertainty to the results. Some recent publications propose the relevance of the paved soils, for example, by substantial SOC and N stocks in subsoil under pavements (Lorenz and Lal, 2009; Piotrowska-Dlugosz and Charzynski, 2015). However, in our research we mapped soil properties in top 0-30 cm layer, which is completely removed during pavement construction. Inclusion of the paved areas into mapping could change the maps by, for example, more abrupt boundaries between polygons or splitting the created maps into sectors, but our outcomes on reconstruction effect on the spatial variability of soil properties are robust.

\section{Conclusion}

Urban parks provide important ecosystem services and recreational facilities and therefore play an essential role in cities. Soils of urban parks are less disturbed and polluted than in most of the other functional zones in cities and therefore are usually considered as urban soil's quality standards. . However, these soils are heterogeneous and temporally dynamic in result of reconstructions and corresponding changes in land-cover structure. In our research we clearly found an effect of reconstruction on soil properties and their spatial variability. The reconstruction of the urban park in Moscow resulted in substantial changes of topsoil properties: a significant increase in SOC and $\mathrm{N}$ contents, decrease in $\mathrm{C}: \mathrm{N}$ ratio and shift in $\mathrm{pH}_{\mathrm{H} 2 \mathrm{O}}$. Transformations of lawns to flower beds and wetlands to trees and shrubs had the most positive effect on soil quality. Although the land-cover structure of the park after the reconstruction was diverse, the reconstruction resulted in homogenization of topsoil features.

On-going urbanization and growing understanding of the importance of sustainable urban development will result in further expansion of green zones by establishing new urban parks as well as by reconstructing existing ones. The findings of the research can be used to project possible 
changes in soil cover resulted from expansion and reorganization of green areas, which is essential to support decisions in urban planning and soil management in sustainable cities.

\section{Acknowledgements}

Soil sampling in the field and sample preparation were supported by the Russian Science Foundation (Project № 16-16-04014). Chemical analyses of soils were performed with the support from Russian Science Foundation (Project № 17-77-20046). Data analysis and soil mapping was prepared with the support of "RUDN University program 5100 ".

\section{References}

Ali, I. and G. Nabi. 2016. Soil carbon and nitrogen mineralization dynamics following incorporation and surface application of rice and wheat residues Carbon mineralization $\mathrm{N}$ mineralization The wheat and rice residue and the soil were treated. Soil and Environment 35(2): 207-215.

Ahmed, H., M.T. Siddique, M. Iqbal and Hussain, F. 2017. Comparative study of interpolation methods for mapping soil $\mathrm{pH}$ in the apple orchards of Murree, Pakistan. Soil and Environment 36(1): 70-76.

Argenbright, R. 2011. New Moscow: an exploratory assessment. Eurasian Geography and Economics 52(6): 857-875.

Bae, J. and Y. Ryu. 2015. Landscape and Urban Planning Land use and land cover changes explain spatial and temporal variations of the soil organic carbon stocks in a constructed urban park. Landscape and Urban Planning 136: 57-67.

Batjes, N.H. 1996. Development of a world data set of soil water retention properties using pedotransfer rules. Geoderma, 71(1-2): 31-52.

Denisov, V.V., A.S. Kurbatova, I.A. Denisova, V.L. Bondarenko, V.A. Grachev, V.V. Gutenev and V. A. Nagnibeda. 2008. Ecology of a city. Russia. 832.

Dovletyarova, E.A., L.V. Mosina, V.L. Vasenev, N.D. Ananyeva, A. Patlseva and K.V. Ivashchenko. 2017. Monitoring and Assessing Anthropogenic Influence on Soil's Health in Urban Forests: The Case from Moscow City. Singapore. Adaptive Soil Management: From Theory to Practices 531-557.

FAO. 2013. How to Feed the World in 2050, 2050 (1): 35

Gerasimova, M.I., M.N. Stroganova, N.V. Mozharova and T.V Prokofieva. 2003. Urban Soils 268.

Ghosh, S., B.C. Scharenbroch and L.F. Ow. 2016. Soil organic carbon distribution in roadside soils of Singapore. Chemosphere 165: 163-172.
Hengl, T., G.B. Heuvelink and D.G Rossiter. 2007. About regression-kriging: from equations to case studies. Computers \& geosciences 33(10): 1301-1315.

Horváth, A., P. Szücs and A. Bidló. 2017. Soil condition and pollution in urban soils: evaluation of the soil quality in a Hungarian town. Journal of Soils and Sediments 15(8): 1825-1835.

Huot, H., J. Joyner, A. Córdoba, R.K. Shaw, M.A. Wilson, R. Walker and Z. Cheng. 2017. Characterizing urban soils in New York City: profile properties and bacterial communities. Journal of Soils and Sediments (2): 393-407.

Ivashchenko, K.V., N.D. Ananyeva, V.L. Vasenev, V.N. Kudeyarov and R. Valentini. (2014). Biomass and respiration activity of soil microorganisms in anthropogenically transformed ecosystems (Moscow region). Eurasian soil science 47(9): 892-903.

Khan, S., S. Munir, M. Sajjad and G. Li. 2017. Urban park soil contamination by potentially harmful elements and human health risk in Peshawar City, Khyber Pakhtunkhwa, Pakistan. Journal of Geochemical Exploration (165): 102-110.

Kislov, A.V. and P.I. Konstantinov. 2011. Detailed spatial modeling of temperature in Moscow. Russian Meteorology and Hydrology 36(5): 300-306.

Kulbachevksy, A.O. 2015. Russia. Report on the environmental state in Moscow in 2014. 1-2

Kurbatova, A.S., V.N. Bashkin and Y. Barannikova. 2004. Ecological Functions of Urban Soils, Russia. 228.

Kurganova, I., V. Lopes de Gerenyu, J. Six and Y. Kuzyakov. 2014. Carbon cost of collective farming collapse in Russia. Global change biology 20(3): 938947.

Levin, M.J., K.H.J. Kim, J.L. Morel, W. Burghardt, P. Charzynski and R.K. Shaw. 2017. Soils within Cities. Stuttgart: Catena 253.

Livesley, S.J., B.J. Dougherty, A.J. Smith, D. Navaud, L.J. Wylie and S.K. Arndt. 2010. Soil-atmosphere exchange of carbon dioxide, methane and nitrous oxide in urban garden systems: Impact of irrigation, fertiliser and mulch. Urban Ecosystems 13(3): 273293.

Lorenz, K., and R. Lal. 2009. Carbon sequestration in forest ecosystems. Springer Science \& Business Media 277.

Lorenz, K., and R. Lal. 2015. Managing soil carbon stocks to enhance the resilience of urban ecosystems. Carbon Management 6(1-2): 35-50.

McBratney, A.B., I.O.A. Odch, T.F.A Bishop, M.S Dunbar, T.M. Shatar. 2000. An overview of pedometric techniques for use in soil survey. Geoderma 97: 293-327. 
McBratney, A.B., M.M. Santos AND B. Minasny. 2003. On digital soil mapping. Geoderma 117(1): 3-52.

McKinney, M.L. 2006. Urbanization as a major cause of biotic homogenization. Biological Conservation 127: 247-260.

Morel, J.L., C. Chenu, and K. Lorenz. 2014. Ecosystem services provided by soils of urban, industrial, traffic, mining, and military areas (SUITMAs). Journal of Soil and Sediments 15(8): 1659-1666.

Nilsson S, E.A. Vaganov, A. Shvidenko, V. Stolbovoi, V.A. Rozhkov, I. McCallum and M. Jonas. 2003. Carbon budget of vegetation ecosystems of Russia. Earth Sciences thesis 1281-1283.

Pickett, S.T.A., M.L. Cadenasso, J.M. Grove, C.G. Boone, P.M. Groffman, E. Irwin and P. Warren. 2011. Urban ecological systems: scientific foundations and a decade of progress. Journal of Environmental Management 331-362.

Pickett, S.T.A., M.L. Cadenasso, J.M. Grove, P.M. Groffman, L.E. Band, C.G. Boone, and M.A. Wilson. 2008. Beyond urban legends: an emerging framework of urban ecology, as illustrated by the Baltimore Ecosystem Study. BioScience (58): 139-150.

Piotrowska-Długosz, A., and P. Charzyński. 2015. The impact of the soil sealing degree on microbial biomass, enzymatic activity, and physicochemical properties in the Ekranic Technosols of Torun (Poland). Journal of Soils and Sediments 15(1): 4759.

Pouyat, R.V., I.D. Yesilonis, M. Dombos, K. Szlavecz, H. Setälä, S. Cilliers and S. Yarwood. 2015. A global comparison of surface soil characteristics across five cities: a test of the urban ecosystem convergence hypothesis. Soil Science 180(4/5): 136-145.

Prokofieva, T.V., I.A. Martinenko and F.A. Ivannikov. 2011. Sisitematika pochv i pochvoobrazuyuschih porod i vozmozhnisti ih vklyucheniya $\mathrm{v}$ obschuyu klassifikatsiyu [Systematics of soils and soil-forming rocks and their possible inclusion in the general classification]. Soil Science 5: 611-623.

Prokofieva, T.V., M.I. Gerasimova, O.S. Bezuglova, K.A. Bakhmatova, A.A. Gol'eva, S.N. Gorbov and N.E. Sivtseva. 2014. Inclusion of soils and soil-like bodies of urban territories into the Russian soil classification system. Eurasian soil science 47(10): 959-967.

Prokofieva, T.V., M.S. Rozanova and V.O. Poputnikov. 2013. Some features of soil organic matter in parks and adjacent residential areas of Moscow. Eurasian soil science 46(3): 273-283.

Raciti, S., P. Groffman, J. Jenkins, R. Pouyat, T. Fahey, S. Pickett and M. Cadenasso. 2011. Accumulation of Carbon and Nitrogen in Residential Soils with
Different Land-Use Histories. Ecosystems (14): $287-$ 297.

Rizwan, M., M.T. Siddique, H. Ahmed, M. Iqbal and T. Ziad. 2016. Spatial variability of selected physicochemical properties and macronutrients in the shale and sandstone derived soils. Soil and Environment 35(1): 12-21.

Rossiter, D.G. 2007. Classification of Urban and Industrial Soils in the World Reference Base for Soil Resources. Journal of Soils and Sediments (7): 96100.

Rozanova, M.S., T.V. Prokof'eva, L.V. Lysak and A.A. Rakhleeva, 2016. Soil organic matter in the Moscow State University botanical garden on the Vorob'evy Hills. Eurasian Soil Science 49(9): 1013-1025.

Sarzhanov, D.A., V.L. Vasenev, Y.L. Sotnikova, A. Tembo, I.I. Vasenev and R. Valentini. 2015. Shortterm dynamics and spatial heterogeneity of $\mathrm{CO}_{2}$ emission from the soils of natural and urban ecosystems in the Central Chernozemic Region. Eurasian soil science 48(4): 416-424.

Shchepeleva, A.S., V.I. Vasenev, I.M. Mazirov, I.I. Vasenev, I.S. Prokhorov and D.D. Gosse. 2017. Changes of soil organic carbon stocks and $\mathrm{CO}_{2}$ emissions at the early stages of urban turf grasses' development. Urban ecosystems 20(2): 309-321.

Shishov L.L. and N.V. Voinovich. 2002. Soils of Moscow Region and Their Use. Russian Dokuchaev Soil Science Institute 500.

Smorkalov, I.A. and E.L. Vorobeichik, 2015. The impact of a large industrial city on the soil respiration in forest ecosystems. Eurasian Soil Science 48(1): 106114.

Stroganova, M.N., A.D. Myagkova and T.V. Prokof'eva. 1997. The role of soils in urban ecosystems. Eurasian soil science 30(1): 82-86.

Svirejeva-Hopkins, A., J.H. Schellnhuber and V.L. Pomaz. 2004. Urbanized territories as a specific component of the global carbon cycle. Ecological Modelling 173: 295-312.

Nations, U. 2014. World Urbanization Prospects: The 2014 Revision, Highlights. Department of Economic and Social Affairs. Population Division, United Nations. 32.

Vasenev, V.I., N.D. Ananyeva and O.A. Makarov. 2012. Specific features of the ecological functioning of urban soils in Moscow and Moscow oblast. Eurasian Soil Science 45: 194-205.

Vasenev, V.I., J.I. Stoorvogel and I.I. Vasenev. 2013. Urban soil organic carbon and its spatial heterogeneity in comparison with natural and agricultural areas in the Moscow region. Catena 107: 96-102. 
Vasenev, V.I., A.S. Epikhina, M.M. Fatiev and I.S. Prokhorov. 2014. Experimental modelling of urban soils' constructions with minimal emissions of greenhouse gases. Agroecology 1: 43-49.

Washbourne, C. L., Renforth, P., \& Manning, D. A. C. 2012. Investigating carbonate formation in urban soils as a method for capture and storage of atmospheric carbon. Science of the Total Environment, 431: 166175.
Yang, J., Yu, F., Yu, Y., Zhang, J., Wang, R., Srinivasulu, M., and Vasenev, V. 2017. Characterization, source apportionment, and risk assessment of polycyclic aromatic hydrocarbons in urban soil of Nanjing, China. Journal of Soils and Sediments, 17(4): 11161125 . 